\title{
NEW RARE CAVE MINERALS FROM THE PEROLAS-SANTANA KARST SYSTEM (SÃO PAULO STATE, BRAZIL) ${ }^{3}$
}

\author{
Paolo FORTI ${ }^{1}$, Ermanno GALLI ${ }^{2}$, Antonio ROSSI ${ }^{2}$
}

\section{RIASSUNTO}

Il sistema carsico Perolas-Santana (Stato di San Paolo, Brasile) era già stato parzialmente studiato in precedenza per quanto riguarda i minerali secondari di grotta. Il presente lavoro costituisce un ulteriore contributo per la sua migliore conoscenza da questo punto di vista avendo permesso di individuare oltre alla presenza di bei cristalli di celestina, un minerale piuttosto raro per l'ambiente carsico: la lithiophorite. Con questi ritrovamenti il sistema carsico PerolasSantana diventa una delle grotte più importanti dal punto di vista mineralogico di tutto il Brasile. I risultati delle analisi chimiche effettuate su frammenti di questo ossido-idrossido di manganese hanno evidenziato una distribuzione zonata degli elementi che lo costituiscono, per cui si può ipotizzare una genesi del minerale in momenti diversi e da soluzioni con chimismo variabile nel tempo.

Parole chiave: lithiophorite, chimismo, minerali di grotta, Perolas-Santana, Brasile.

\section{ABSTRACT}

The Perolas-Santana karst system (São Paulo State, Brazil) has been partially studied from the mineralogical point of view. The present paper will contribute to the knowledge of the minerals in these caves, describing the occurrence of euhedral celestite crystals and of a rather rare mineral for a cavern environment: lithiophorite. Thanks to these new discoveries the PerolasSantana karst system becomes one of the most important in Brazil from a mineralogical point of view. Finally, the result of the chemical analyses carried out on this newly discovered Mnoxyhydroxide put in evidence a zonation in the distribution of the different elements which may be related to several subsequent depositional events characterized by solutions with a chemical content variable in time.

Keywords: lithiophorite, chemistry, cave minerals, Perolas-Santana, Brazil.

1 Istituto Italiano di Speleologia, Università di Bologna, Via Zamboni 67, 40127 Bologna, Italy. forti@geomin.unibo.it

2 Dipartimento di Scienze della Terra, Università di Modena e Reggio Emilia, Via S.Eufemia 19, 41100 Modena, Italy. gallier@unimo.it

${ }^{3}$ Research supported by MURST and CNR grants. 


\section{Introduction}

Until present only a couple of preliminary researches were carried out on the secondary cave minerals of the Perolas-Santana karst system (Barbieri, 1993; Labegalini \& Auler, 1997): they report the study of several speleothems, all of which are relatively common for the cave environment. They evidenced the widespread presence of secondary deposits of calcite, aragonite, hydromagnesite, gypsum and limonite. Moreover, thin leucophosphite and hydroxylapatite crusts were reported only for the Santana cave (Tab.1).

Table 1. Cave minerals actually known from the Perolas-Santana karst system (the asterisk marks those discovered during the present research, the question mark indicates that it is not completely demonstrated the secondary origin of illite)

\begin{tabular}{|l|l|l|l|}
\hline & Mineral & Formula & Occurrence \\
\hline & Aragonite & $\mathrm{CaCO}_{3}$ & Cave pearls, helictites, moonmilk, stalactites \\
\hline & Calcite & $\mathrm{CaCO}_{3}$ & All kinds of speleothems \\
\hline$*$ & Celestite & $\mathrm{SrSO}_{4}$ & Small euhedral crystals \\
\hline & Gypsum & $\mathrm{CaSO}_{4} 2 \mathrm{H}_{2} \mathrm{O}$ & Crystals, crusts, helictites \\
\hline & Hydromagnesite & $\mathrm{Mg}_{5}\left(\mathrm{CO}_{3}\right)_{4}(\mathrm{OH})_{2} 4 \mathrm{H}_{2} \mathrm{O}$ & Moonmillk, powder \\
\hline \multirow{2}{*}{$(?)$} & Hydroxylapatite & $\mathrm{Ca}_{5}\left(\mathrm{PO}_{4}\right)_{3}(\mathrm{OH})$ & Crusts, powder \\
\hline & $\begin{array}{l}\left(\mathrm{K}, \mathrm{H}_{2} \mathrm{O}\right)(\mathrm{Al}, \mathrm{Mg}, \mathrm{Fe})_{2} \\
\left(\mathrm{Si}, \mathrm{Al}_{4} \mathrm{O}_{10}\left[(\mathrm{OH})_{2}, \mathrm{H}_{2} \mathrm{O}\right]\right.\end{array}$ & $\begin{array}{l}\text { Hard translucent grey masses dispersed in the } \\
\text { lithiophorite rich crusts }\end{array}$ \\
\hline & Leucophosphite & $\mathrm{KFe}_{2}\left(\mathrm{PO}_{4}\right)_{2}(\mathrm{OH}) 2 \mathrm{H}_{2} \mathrm{O}$ & Crust, powder \\
\hline$*$ & Limonite & & Thin crust over pyrite \\
\hline
\end{tabular}

In 2001 the Italian Institute of Speleology together with the Department of Environmental and Marine Sciences of the University of Triest performed an hydrogeological (Ayub et al., 2001) and geomorphologic (Forti et al., 2001) study of this karst system. During this research some secondary cave deposits were sampled to improve the knowledge on the minerogenetic processes active inside these caves. Therefore the widespread calcite, aragonite, hydromagnesite and gypsum speleothems were not taken into consideration because they were already well described, but a single phosphate deposit has been sampled because most of them were located in areas not reached during this study. 
The research was mainly focused on some blackish crusts found inside the Perolas cave and some small pale blue crystals growing around and over the large gypsum deposits in the Santana cave. The analyses of these cave samples permitted the detection of lithiophorite and celestite (and perhaps illite), which are rather rare in a cave environment (Hill \& Forti, 1997).

In the present paper, after a short geological and hydrogeological overview on the Perolas-Santana karst system, the analysed samples are described from the mineralogical point of view together with the possibile genetical mechanism that allows for their depositing inside these caves. Accurate analyses were made on the samples of lithiophorite, a Mn-phyllomanganate characterized by a very variable chemical composition, which is controlled both by the possible ionic substitution inside its crystal structure and by the typical occurrence of the mineral as finegrained masses strictly intergrown with other manganese oxides.

\section{Geological and hydrogeological overview}

The Pérolas-Santana system is located on the SW slope of the Serra di Paranapiacaba in the high Ribeira river valley, Iporanga municipality, south-east-

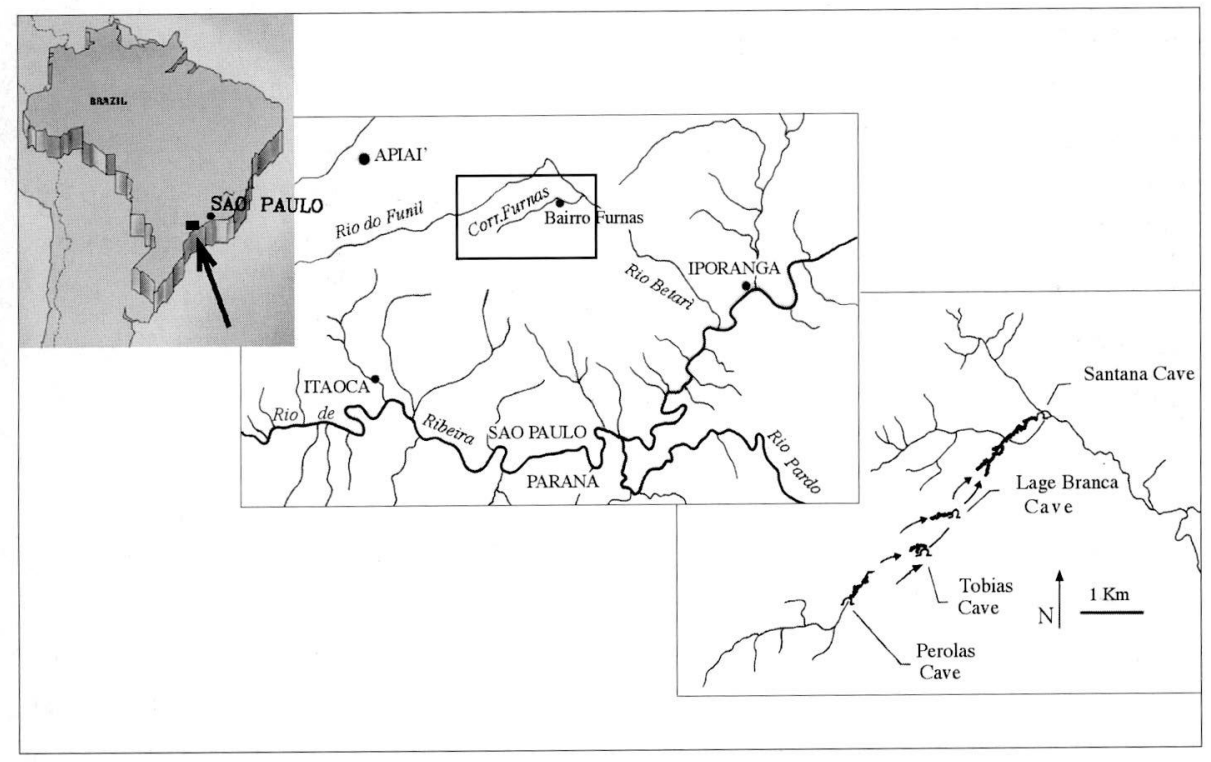

Fig. 1- Index map and sketch for the Perolas-Santana karst system 
ern sector of the São Paulo State, Brazil (Karmann \& Sanchez, 1986; Karmann, 1994) (Fig. 1). The area is characterized by several highlands with an average elevation of $700 \mathrm{~m}$ asl with mountains reaching $1000 \mathrm{~m}$. The weather is tropical humid (Gutjahr, 1993) without any dry period. The rainfall ranges between 1500 and $1850 \mathrm{~mm} / \mathrm{yr}$ (1604 $\mathrm{mm}$ being the average over the period 1974-1993) and are equally subdivided along the year with about 10 "strong" events. The temperature ranges from $20^{\circ} \mathrm{C}$ (average minimum) to $27^{\circ} \mathrm{C}$ (average maximum). This climate induces the development of a thick vegetable cover, locally known as «Mata Atlantica».

The area is characterized by the outcropping of rocks belonging to the Açungui Group, which consist mainly of gneiss and migmatites with marble and quartzite intercalations (Campanha, 1991). The recharge area of the Perolas-Santana develops in low rank metamorphic rocks (arkosic sandstones with quartz conglomerate intercalations, siltstones, limestones and dolostones). Normally the limestones are more or less dolomitic and partially recrystallized, sometimes with a low marl content; they have from small to medium grain size, a dark grey colour and are clearly stratified. Locally they present some intercaltions of phyllites which in turn are rich in iron oxides-hydroxides and illite. The limestone-dolostone unit underlies quartz-sericite phyllites and schists.

The surface of carbonate rock is characterized by covered tropical karst features, with extremely scarce outcrops and huge doline-like depressions. Most of these depressions receive streams flowing in small lateral valleys and have active sinkholes at the bottom. The high evapotranspiration together with the scarce permeability of the thick soils avoids a diffuse infiltration and therefore the recharge of the karst aquifer occurs mainly through the sinkholes while the seepage in areate zone remains very low.

The aquifer is characterized by a few main drainage tubes, represented by wide often well decorated galleries partially occupied by collapse boulders. The development of the cave passages is driven by the dip of the strata, which are often subvertical. The Perolas and Santana caves are respectively the upstream and the downstream part of the karst system, which is crossed by a perennial river with a base flow of about $0.01 \mathrm{~m}^{3} / \mathrm{s}$.

Floods occur a few hours after main episodes of rainfall and they induce an increase in the water level of over $1 \mathrm{~m}$. The hydrodynamics of the system are so fast that the floods last only 4-6 hours. 


\section{Experimental Methods}

A detailed analysis of all the samples by the stereoscopic microscope was performed to distinguish and to separate the different mineralogical phases present in each sample. Then the single phases were analysed by a powder diffractometer (Philips PW 1050/25), when the material was quantitatively sufficient and homogeneous, or by a Gandolfi camera ( $\varnothing: 114.6 \mathrm{~mm}$, exposition: $48 \mathrm{hrs}$ ), when the material was scarce or inhomogeneous. The experimental conditions were always: $40 \mathrm{Kv}$ e $20 \mathrm{~mA}$ tube, CuKa, Ni filtered radiation $(\lambda=1.5418 \AA)$. The same samples analyzed in the Gandolfi camera were later used to obtain images and chemical qualitative analyses through an electron scanning microscope (SEM Philips XL40) with an electronic microprobe (EDS - EDAX 9900) in the "Centro Interdipartimentale Grandi Strumenti" of Modena and Reggio Emilia University. Quantitative chemical analyses were performed with an ARL-SEMQ electron microprobe operating in a wavelength dispersive mode at $20 \mathrm{keV}$, with a $20 \mathrm{nA}$ sample current and $30 \mu \mathrm{m}$ beam diameter. The standard used were BH1 microcline $(\mathrm{Si}, \mathrm{K}), \mathrm{BH} 5$ spessartine $(\mathrm{Al}, \mathrm{Mn}), \mathrm{BH} 7$ ilmenite $(\mathrm{Fe}, \mathrm{Ti})$, paracelsian $(\mathrm{Ba})$, metal Co $100 \%(\mathrm{Co}), \mathrm{Ni}_{80} \mathrm{Cr}_{20}(\mathrm{Ni}), \mathrm{Cu}_{63} \mathrm{Zn}_{37}(\mathrm{Cu}, \mathrm{Zn})$, stoichiometric $\mathrm{Ca}_{2} \mathrm{P}_{2} \mathrm{O}_{7}$ (P), REE3 glass $(\mathrm{Ca}, \mathrm{Ce})$; data acquisition and processing by the PROBE program (Donovan, 1995).

Water content was determined by thermogravimetric analysis on $12.02 \mathrm{mg}$ of sample using a Seiko SSC/5200 operating at $10^{\circ} / \mathrm{min}$ to $1000^{\circ}$ in air. $\mathrm{Li}_{2} \mathrm{O}, \mathrm{Na}_{2} \mathrm{O}$ and $\mathrm{MgO}$ were detected with an Atomic Absorption Spectrometer (AAS) PerkinElmer mod. Analist 100.

\section{Morphology of the samples and identification of the their mineralogical phases}

Four different samples were taken along the main gallery of Perolas Cave, where the underground river flows:

Per. 1: Fragment of a blade shaped pendant (Fig. 2), the evolution of which was caused by the erosive action of the water during the floods. The sample was taken from the main gallery ceiling. It is a fragment of an orange calcite speleothem with a compact structure and rare small cavities, which is completely covered by a millimetric black translucent crust. In a single part, between the calcite speleothem and the overgrown black crust, there are small lens-shaped pockets of very thin sedimentary materials, in which quartz and mica crystals can be recognized by the naked eye. 


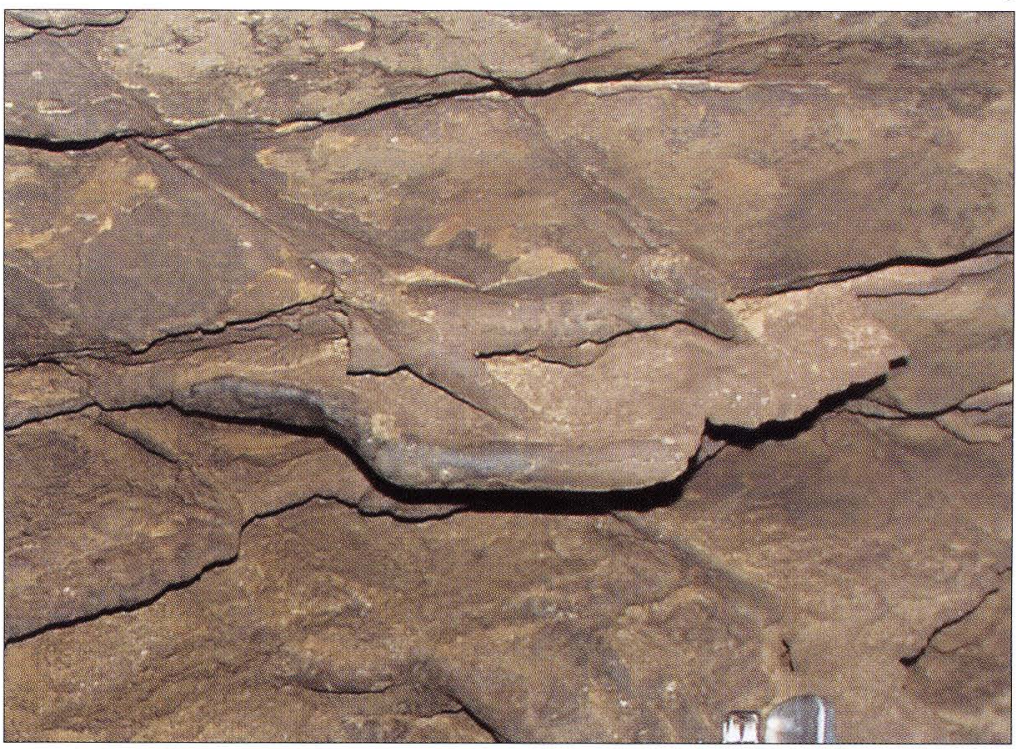

Fig. 2 - The boxwork sampled (Per. 1) in the Perolas cave: the black thin outer crusts proved to be lithiophorite

The Rx analyses show that this speleothem consists of calcite while the sediments in the pockets are composed of illite, quartz chlorite and feldspar. The definition of the mineralogical composition of the black crust was rather more complicated, because it consists of several very thin superimposed layers and is poorly crystallized. Its determination was possible only by using a Gandolfi camera with an exposure of over 48 hours, and it was confirmed later by an E.D.S. analysis: the mineral forming the crust is lithiophorite, a Mn-oxyhydroxide rather rare in the cave environment.

Per. 2: Fragment of a pale brown speleothem taken about $70 \mathrm{~cm}$ above the base level of the underground river. On its surface there are clear solution grooves parallel to the speleothem elongation. Diffractometric analysis results showed pure calcite.

Per. 3: Fragment of a lens-shaped boxwork $1 \mathrm{~cm}$ thick consisting of an illitic micaschist with a trace of feldspar. It was hanging from a balcony $30 \mathrm{~cm}$ over the base level of the river and evidently was involved by strong water flow during the flooding. The fragment consists of a iron grey translucent schist covered by a thin layer of an earthy, fine grained, brown material. The general aspect is of a material which underwent strong erosion and/or corrosion. It consisted of pure illite as evidenced by Rx analyses. 
Per. 4: Fragment of a $3 \mathrm{~cm}$ thick crust grown over a large boulder which was in the past interested by water flow during the flooding (Fig. 3). It consists of a black microcrystalline, often cracked material, with some thin layers and/or pockets of a thin grained sedimentary pink yellowish material with many rounded quartz fragments inside. The black material normally has an earthy aspect but sometimes consists of a crust of small shining metallic spherical aggregates; each sphere is

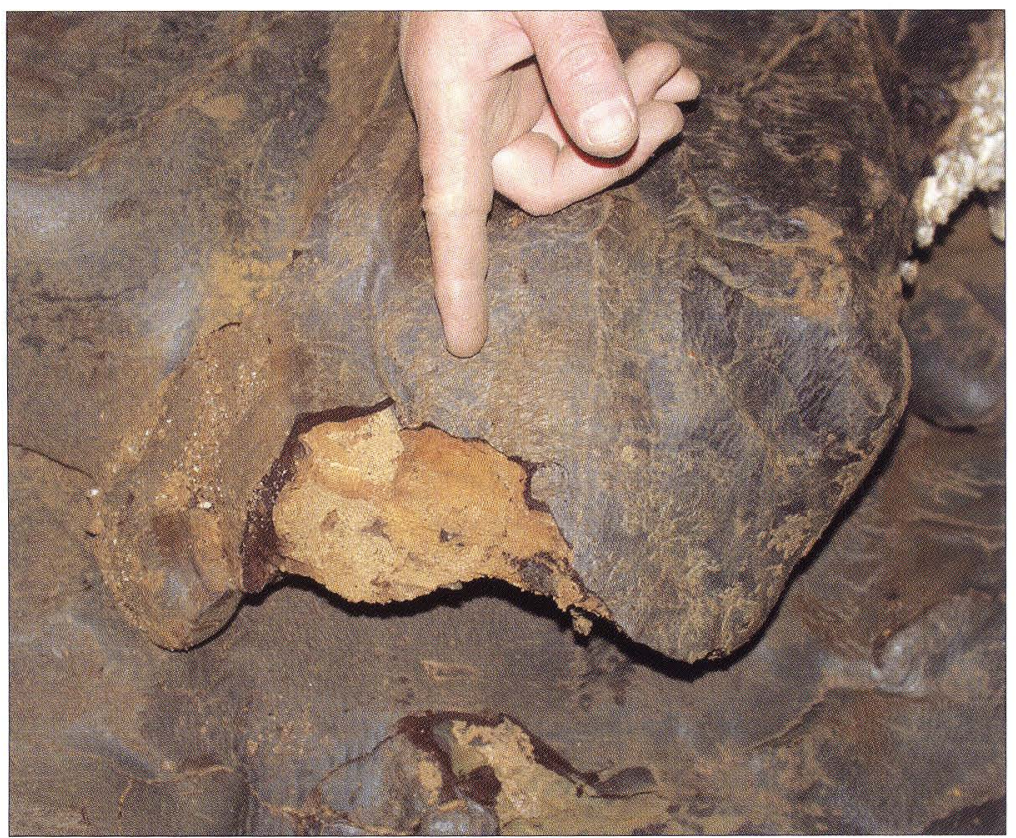

Fig. 3 - The thick lithiophorite crusts of Per. 3 sample

composed of thin concentric layers with an onion-like sheeting. Some transparent vitreous euhedral elongated prismatic crystals are present over the sphere surfaces, and inside of fractures and small cavities. Diffractometric and Gandolfi camera analyses proved that the black material is lithiophorite, the sandy one is illite and quartz, while the transparent crystals are calcite.

Five samples were taken from Santana Cave, all of them in the area where the maximum concentration of gypsum occurs in order to define mineralogically some small speleothems growing over the gypsum and/or over corroded calcite formations. 
San. 1: This sample was taken from a subvertical wall (Fig. 4) and consists of: a) a small fairly radiate aggregate of elongated prismatic pale-blue crystals $(0.3 \times 0.2$ x $5 \mathrm{~mm}$ ) of celestite as proved by diffraction; b) a thin crust $(10 \times 18 \times 4 \mathrm{~mm})$ of prismatic crystals developing over a milky-white powder composed of pure calcite; c) an aggregate of transparent euhedral monoclinic tabular crystals that

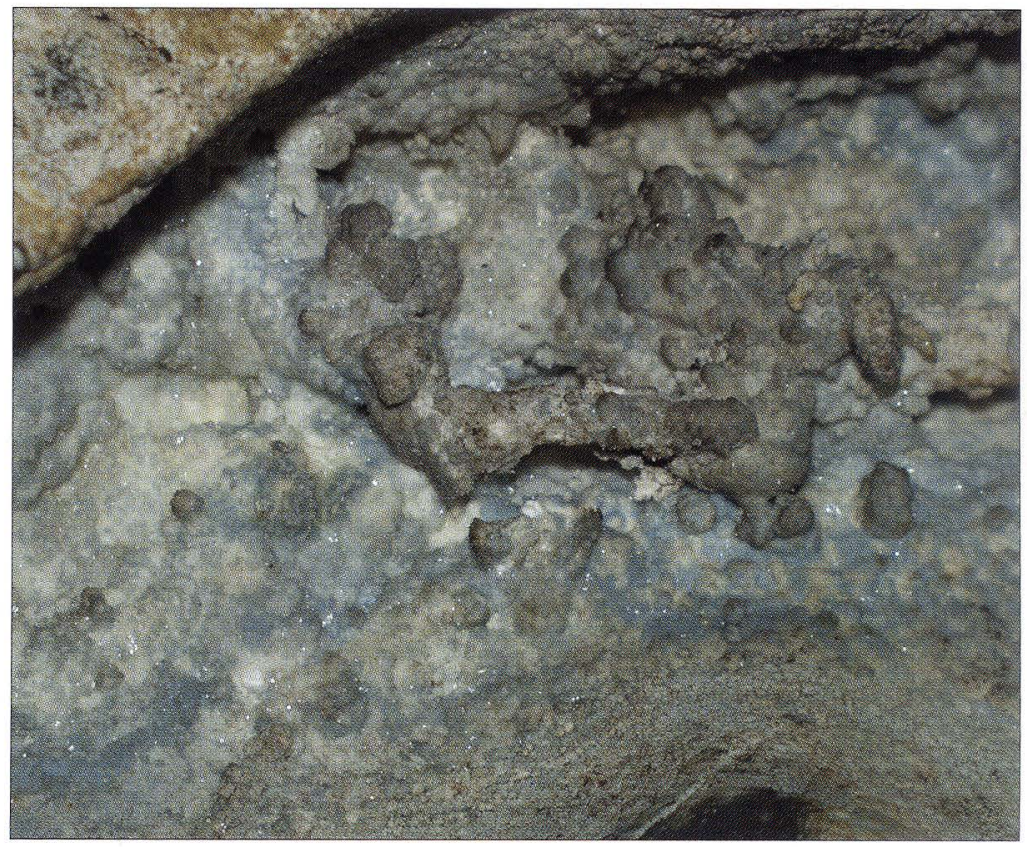

Fig. 4 - Small pale blue-grey celestite crystals over a gyspum crust (San. 1 sample)

proved to be gypsum; d) two small cylindrical fragments (6 x $11 \mathrm{~mm}$ e $6 \times 7 \mathrm{~mm})$ of a helictite (Fig. 5). From outside to inside, both of the fragments consist of a thick aggregate of celestite crystals grown over the helictite, several thin layers of calcite representing the main structure of the speleothem, and finally the feeding hole was partially filled by calcite microcrystals sometime associated with small pockets of aragonite powder.

San. 2: Small rosette aggregates (Fig. 6) of vitreous, transparent, tabular prismatic, irregular crystals of celestite $(0.2 \times 0.2 \times 2 \mathrm{~mm})$ growing over an earthy, pale hazel-brown material.

San. 3: White-greyish earthy powder associated with a lithic vacuolar pale hazel- 


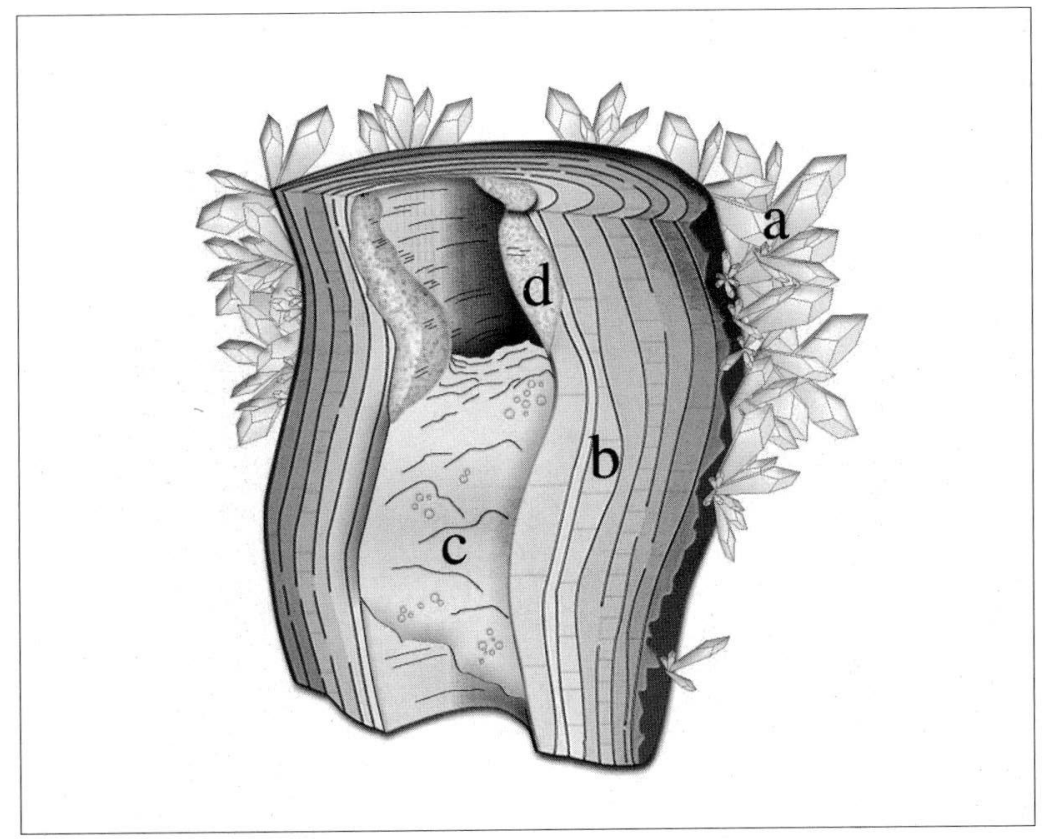

Fig. 5 - Sketch of the helictite present in the San. 1 sample: a) celestite; b) calcite layers; c) calcite microcrystals; d) aragonite powder

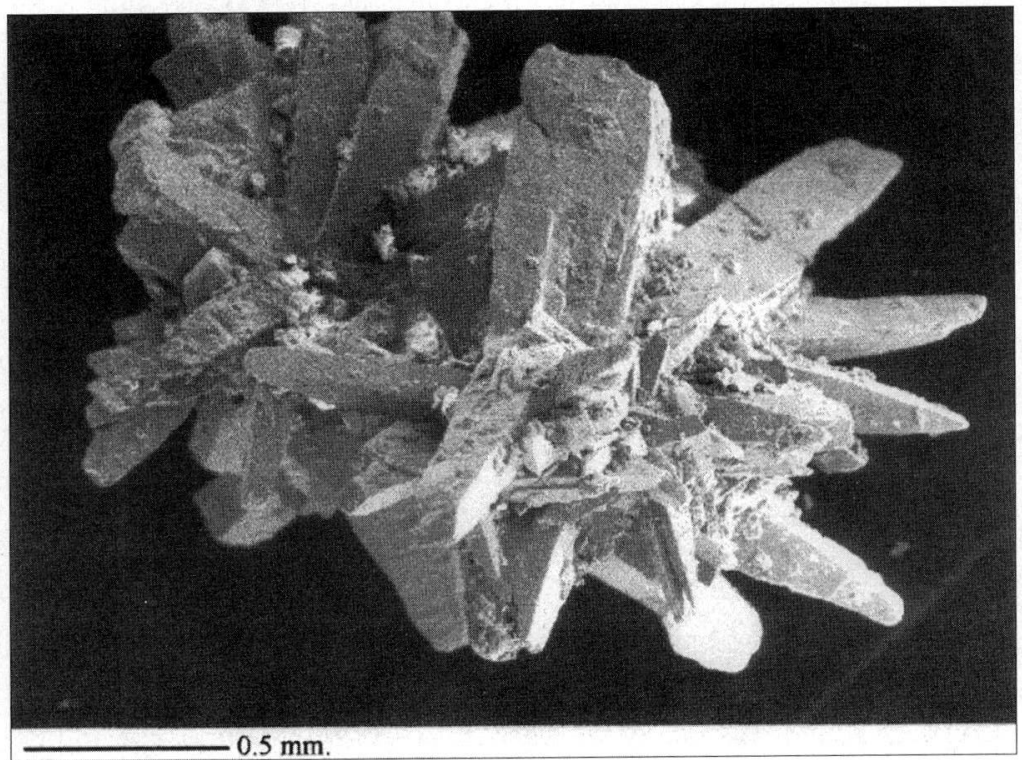

Fig. 6 - SEM image of a rosette aggregate of celestite crystals from San. 2 sample 
brown material developed over a strongly corroded stalagmite (Fig. 7): both proved to be apatite.

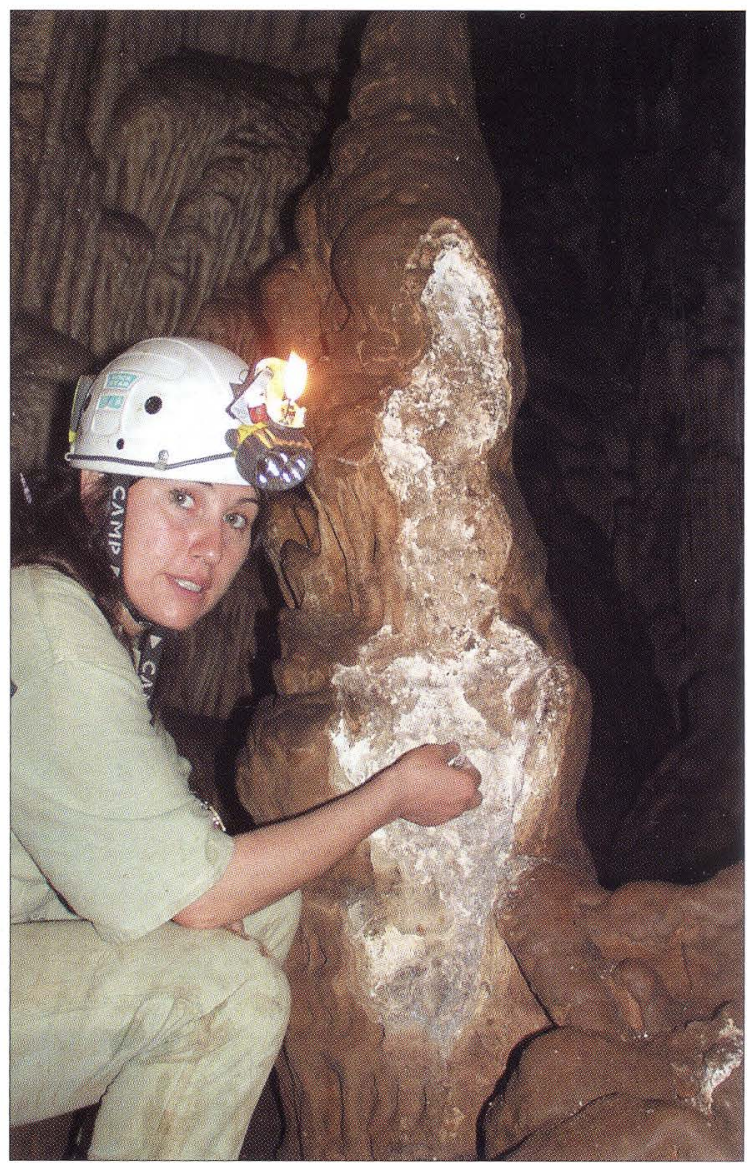

Fig. 7- Santana cave: a calcite stalagmite heavily corroded by sulphuric acid and partially transformed into apatite

San. 4: Pale green-greyish clayey material with a fairly greasy flat or partially rough surface and containing several small white spheroidal masses taken in the floor close to sample San. 3. This sample consists of apatite.

San. 5: A pale grey sand often cemented by a thin crust of variable thickness and/or color: the sand was made by quartz, illite, clorite and felspar and the crust by calcite. 


\section{Results and Discussion}

In the sample from the Santana cave the analyses always shown the presence of celestite $\left(\mathrm{SrSO}_{4}\right)$, the deposition of which evidently represented the final stage in the chemical deposition of the sulphates when all the available solution evaporated.

Celestite in the Santana cave is present as crusts of pale-blue, prismatic parallel crystals, in rosette aggregates or in euhedral crystals elongated [100], with equant cross, $\{210\}$ forms prevalent, the $\{011\}$ and $\{101\}$ forms are commonly exhibited, while the $\{001\}$ one is quite absent (Fig. 8). Over a face of the prism $\{210\}$ biogenic structures are evident, which are probably related to the sulfur-oxidizing

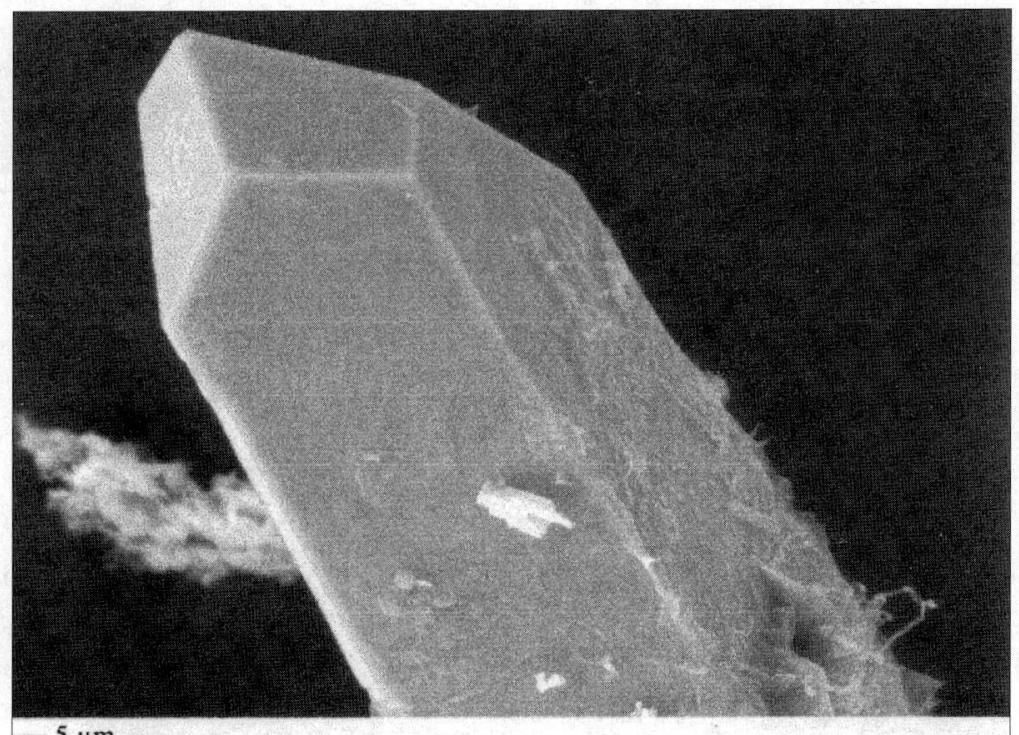

$-5 \mu \mathrm{m}$.

Fig. 8 - SEM image of a celestite single crystals from Sanl sample with evident biogenic structures

micro-organisms, responsible for the production of the $\left[\mathrm{SO}_{4}\right]^{2-}$ ions which in turn caused the mineral crystallization. As for most of the caves in which celestite is present (Hill \& Forti, 1997) the source for the strontium is surely represented by the carbonate rock in which Perolas cave is developed. The sulphate ion comes from the oxidation of pyrite crystals, which are fairly common inside the dolostone walls of the cave (Fig. 9), and which are exposed to weathering by meteoric seeping waters. 


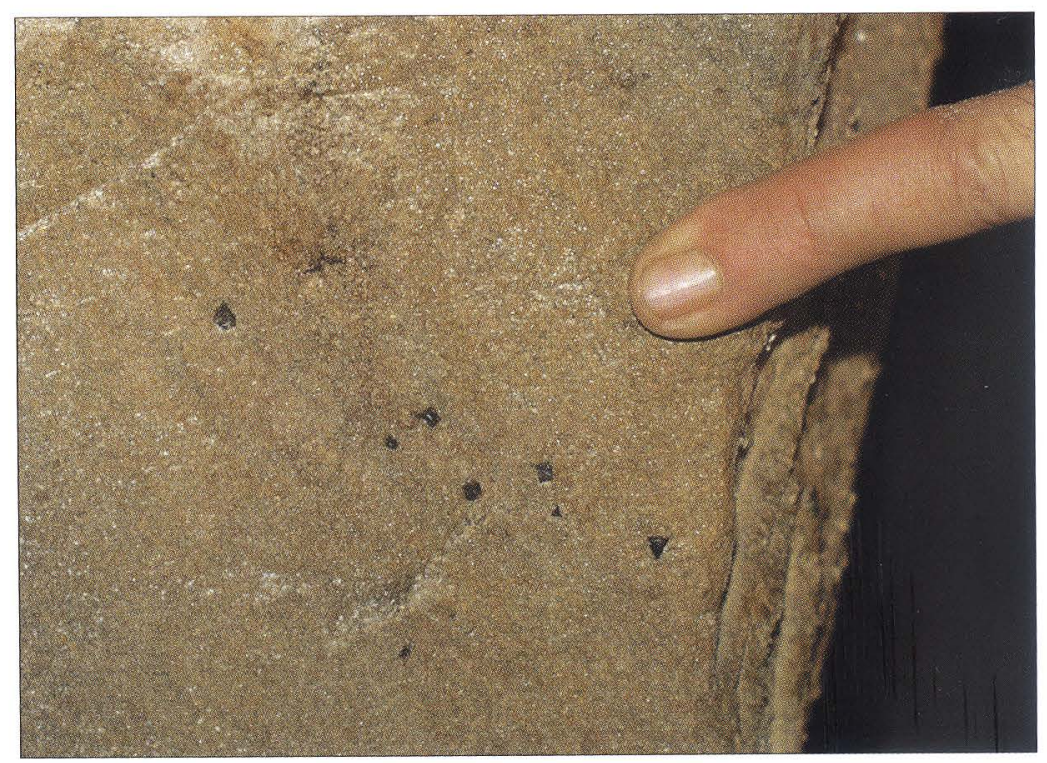

Fig. 9 - Perolas cave: small pyrite crystals exposed by karst erosion and partially transformed into limonite

In the samples San. 3 and San. 4 a mineral of the apatite group was detected, that correspond to the hydroxylapatite already sampled in the same place and characterised by Barbieri (1993): therefore no further analyses was performed on them. The analyses of the samples from Perolas cave detected several minerals, some of which cannot be considered true "cave minerals". In fact, all the chlorite, quartz, feldspar and most of the illite, present as sandy clayley sediments in the Per. 1 and Per. 4 samples, are clearly the products of the erosion over the rocks present in the recharge area of the underground river.

Calcite is surely primary in origin in the Per. 1 (fragment of a limestone rock), while is a true cave minerals in Per. 2 (a corroded speleothem) as well as in Per. 4, where the euhedral vitreous transparent crystals formed via evaporation during the long periods in which the area is not interested by an active water flow. These calcite crystals are elongated along the prism $\{10-10\}$, which is also the predominant form (Fig. 10a), and terminate with the rhombohedron $\{01-11\}$, the faces of which host strange micro-stalactitic growing structures (Fig. 10b).

Illite has often been reported in caves, but most of these reports refer to detrital (residual) occurrences. The first cave in which illite has been demonstrated as being secondary in origin was Fata Morgana cave in Turkmenistan (Lazarev \& 


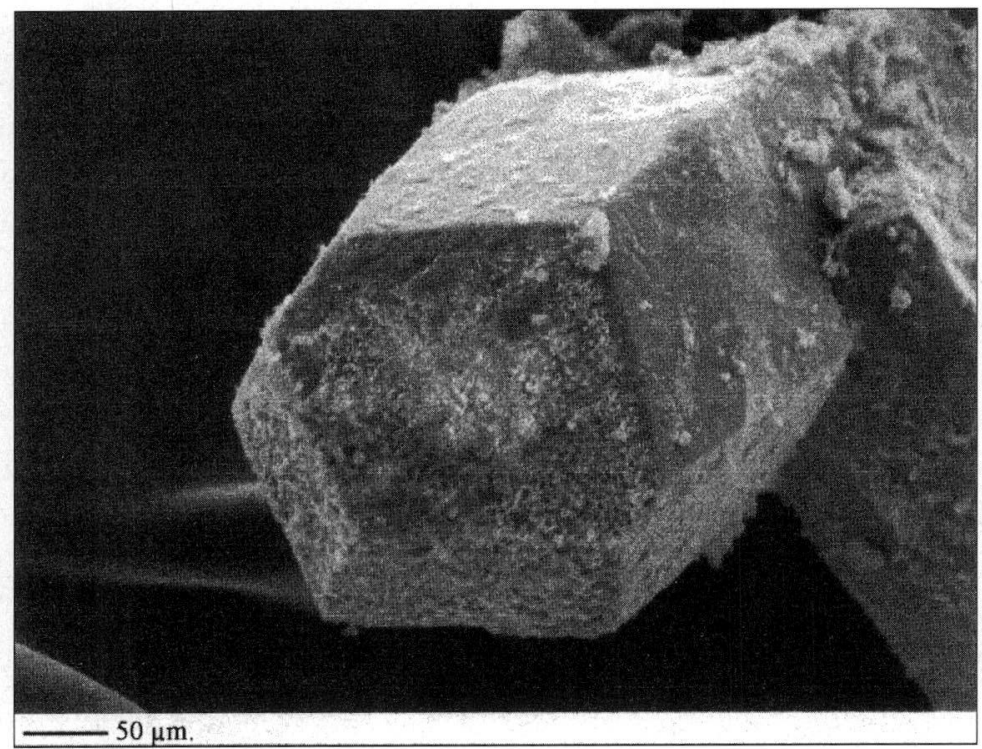

A

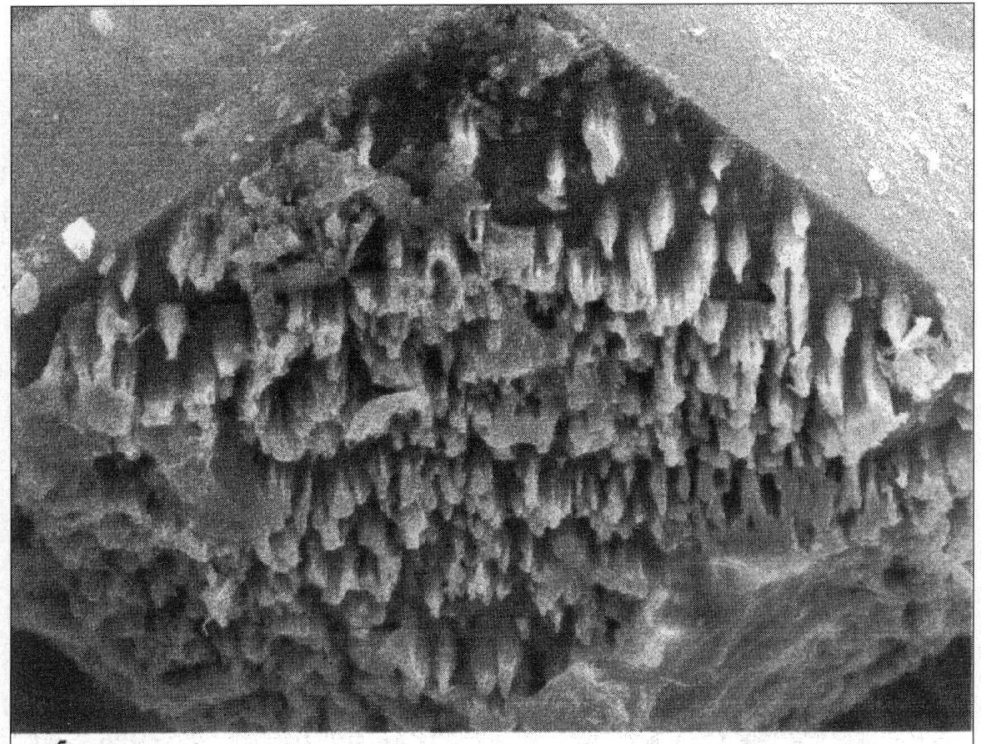

$-5 \mu \mathrm{m}$

B

Fig. 10 - SEM image of secondary calcite crystals from Per. 4 sample: A) general view of a crystal elongated along the $\{10-10\}$ prism, and terminated with the rombohedron $\{01-11\}$, over the faces of which strange micro-stalactitic accretion figures occur $(B)$ 
Philenko, 1976) and after in other caves of the same region (Maltsev, 1993). In these occurrences illite was present up to $20 \%$ in a terrigenous sediment and under the electron scanning microscope illite was found to form euhedral crystals up to $1 \mu$ in size. The origin of this mineral (Hill \& Forti 1997) relates to the weathering of silicate minerals within the cave environment induced by frequent changes in humidity in an acidic environment $(\mathrm{pH}=4.5-5.5)$ : this genetic mechanism fits perfectly with the Perolas occurrence of illite and it is therefore reasonable to define at least one part of the illite present in the samples Per. 1 and Per. 4 as "secondary cave mineral". In fact both these samples were taken in places cyclically flooded and then dried for relatively long periods. An acidic environment is also guaranteed by the actively oxidizing processes of pyrite dispersed in the carbonate rock, while the initial silicates are present both in the phyllite intercalations and in the debris coming from the catchment area.

The idea that illite should be at least partially secondary is strengthened by its occurrence together with lithiophorite, surely a secondary cave mineral, which needs exactly the same environmental conditions. The presence of high amount of lithiophorite in the Perolas cave allowed for detailed investigation on its morphology and, for the first time, on its chemical variance in a cave environment.

\section{Lithiophorite}

Lithiophorite ([( $\left.\mathrm{Al}, \mathrm{Li}) \mathrm{MnO}_{2}(\mathrm{OH})_{2}\right]$ a trigonal oxyhydroxide of $\mathrm{Mn}$ with a low quantity of Li and with $\mathrm{a}_{0}=2.925, \mathrm{c}_{0}=28.169 \AA$, Sp. Gr. R-3m has been known since 1870 (Frenzel, 1870), but for many years it has been considered to be "wad", a generic term still utilised to define some varieties of undifferentiated Mn oxides. Lithiophorite was defined as distinct mineral by Ramsdell only in 1932, and was described as widely occurring in soils, in ocean-floor Mn-crusts, and in weathering zones of ore deposits. Normally lithiophorite occurs as fine-grained masses, but sometimes also as relatively large euhedral crystals. It is rather rare as a cave mineral, up to present being reported only as a minor component of stalagmites in the Martel Cave of the Sima Menor de Sarisariñama, Venezuela (Urbani et al., 1976) and in the Aleko Cave, Bulgaria (Shopov, 1993). The lithiophorite is characterized by a layer structure with alternate sheets of $\left[\mathrm{Mn}^{4+} \mathrm{O}_{6}\right]$ and $\left[(\mathrm{Al}, \mathrm{Li})(\mathrm{OH})_{6}\right]$ octahedra at an interval of $10 \AA$ (Wadsley, 1952; Post \& Appleman, 1994).

The available chemical analyses of lithiophorite coming from several different localities in the world put in evidence a extremely variable Li content (from 0.2 to 3.3 oxide weight percent) (Mitchell \& Meintzer, 1967; Ostwald, 1988). Many 
other elements $(\mathrm{Co}, \mathrm{Cu}, \mathrm{Zn}, \mathrm{Ni})$ may easily enter in the structure replacing the centro-octahedral aluminium (Post \& Appleman, 1994).

The Perolas lithiophorite occurs as millimetric crusts of small spheroidal glassy to metallic-luster grains, the structure of which is layered and apparently homogeneous. Fig. 11 A, B, C and D shows the SEM images of one of these spheroidal grains where its laminar concentric structure and the dishomogeneity of its single growing layers are evident. All the chemical analyses and the thermogravimetric analysis have been conducted on fragments checked for purity by X-ray diffraction using a Gandolfi camera in order to avoid impurities. The content of $\mathrm{Li}_{2} \mathrm{O}$, $\mathrm{Na}_{2} \mathrm{O}$ and $\mathrm{MgO}$, carried out by AAS, were $0.19,0.84$ and 0.45 respectively, while the water content determined by TG was $20.36 \%$.

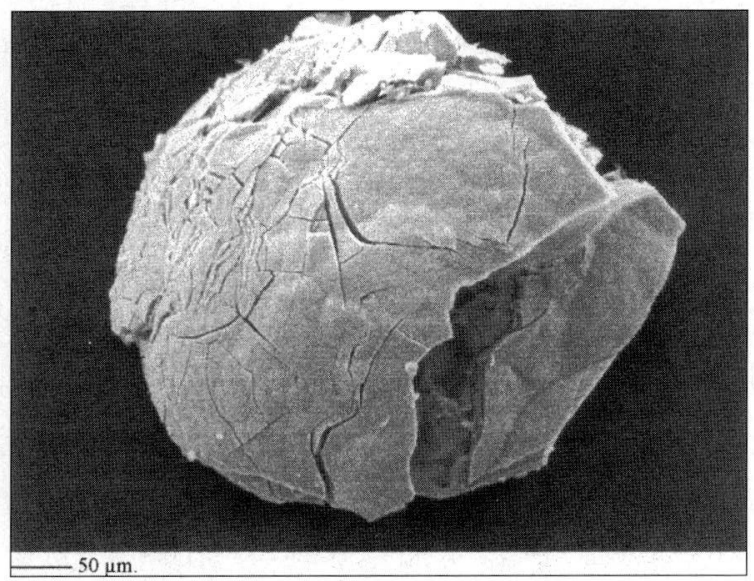

A

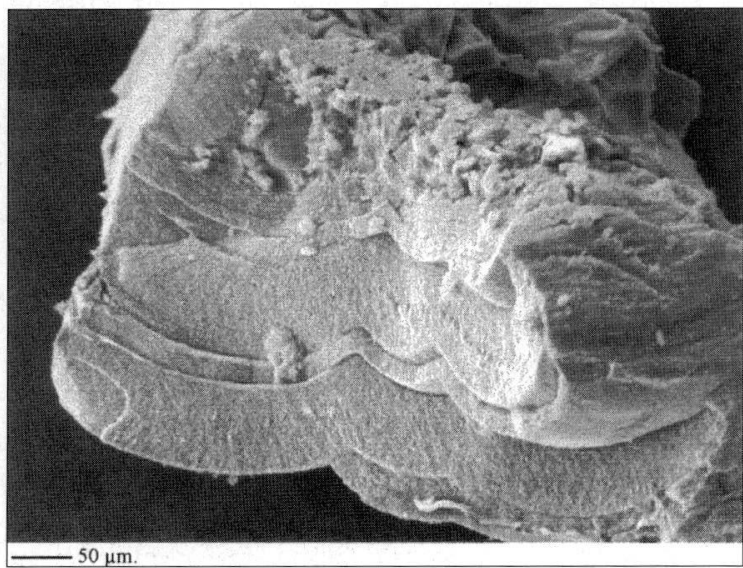

B

Fig. 11-SEM image of a spheroidal grain of lithiophorite from Per. 4 sample: A) external view with evident dehydration cracks; B) internal laminated structure. 


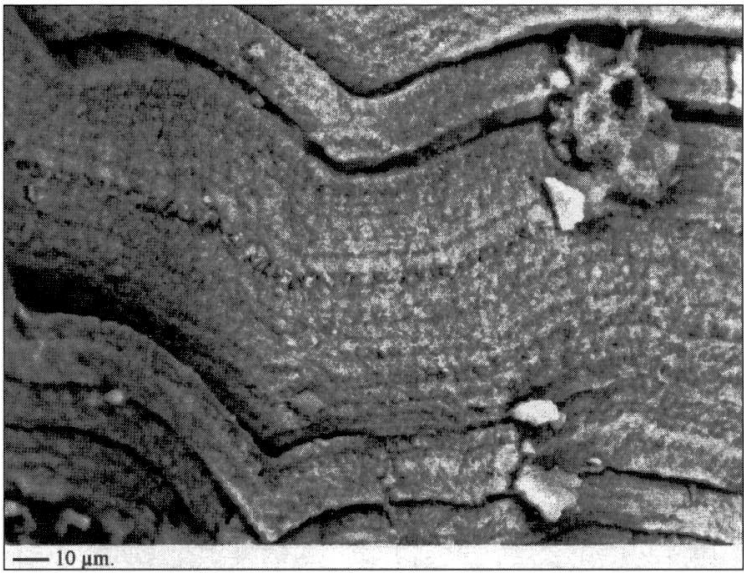

$\mathrm{C}$

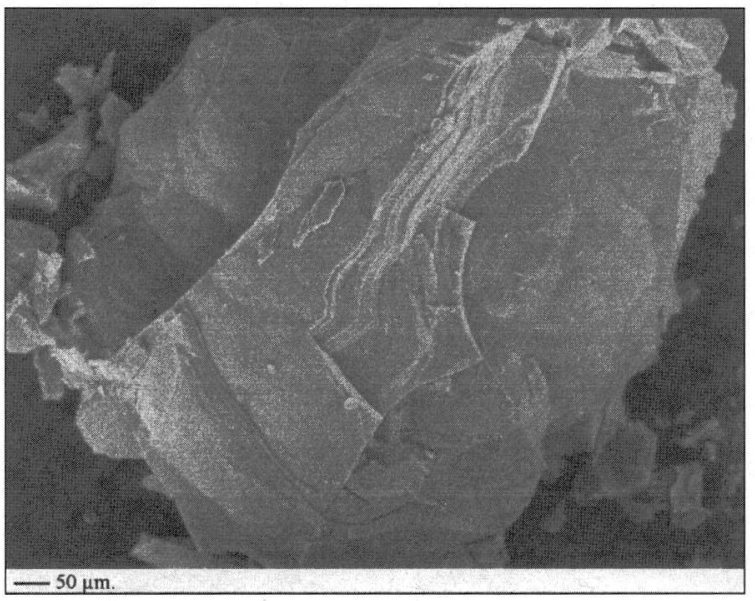

$\mathrm{D}$

Fig. 11- SEM image of a spheroidal grain of lithiophorite from Per. 4 sample: C) enlargement of the B image to make evident the dishomogeneity inside each layer; $D$ ) fragment utilized to obtain the SEM element maps of Fig. 12

Obviously the values are average ones having used only discrete fragments and not spot analyses.

The Li content of the Perolas lithiophorite $(0.19 \%)$ is one of the lowest among those in the literature, similar to that $(0.2 \%)$ of the cave lithiophorite from the Sima Menor de Sarisariñama, Bolivar (Urbani, 1996) and of the non cave lithiophorite from Charlottesville, Virginia (Mitchell \& Meintzer, 1967): anyway it must be cited that Ostwald (1988) put forth the hypothesis that a non-lithium-con- 
taining lithiophorite may also exist.

Table 2 lists the values of 29 individual chemical point-analyses carried out on 6 small fragments of lithiphorite, along with their mean values, arranged in three chemically homogeneous groups.

It is evident that the mean values for $\mathrm{K}_{2} \mathrm{O}(0.08-0.23), \mathrm{CoO}(0.74-0.98), \mathrm{TiO}_{2}$ (0.03-0.21) are rather constant, while the values for $\mathrm{CaO}(0.44-1.17)$, $\mathrm{FeO}(0.17-$ $0.72)$, $\mathrm{NiO}$ (0.55-1.11), $\mathrm{Cu}_{2} \mathrm{O}$ (0.82-1.47), $\mathrm{ZnO}$ (1.17-1.74), $\mathrm{P}_{2} \mathrm{O}_{5}(0.12-1.00)$ present a moderate variability, and those for $\mathrm{BaO}$ (1.13-6.13), $\mathrm{MnO}$ (40.08-49.76), $\mathrm{SiO}_{2}$ (2.10-4.77), $\mathrm{Al}_{2} \mathrm{O}_{3}(10.53-21.19), \mathrm{Ce}_{2} \mathrm{O}_{3}(0.98-15.49)$ a very high variabili-

Table 2. Chemical analyses of lithiophorite from Perolas cave

\begin{tabular}{|c|c|c|c|c|c|c|c|c|c|c|c|c|c|c|}
\hline $\mathrm{N}^{\circ}$ & $3 \mathrm{aO}$ & $\mathrm{AnO}$ & $\mathrm{FeO}$ & $\mathrm{CoO}$ & $\mathrm{NiO}$ & $\mathrm{Cu}_{2} \mathrm{O}$ & $\mathrm{ZnO}$ & $\mathrm{Ce}_{2} \mathrm{O}_{3}$ & iO2 & $\mathrm{CaO}$ & K2O & $\mathrm{P}_{2} \mathrm{O}_{5}$ & $\mathrm{SiO}_{2}$ & $\mathrm{l}_{2} \mathrm{O}_{3}$ \\
\hline & & & & & & & & & & & & & & \\
\hline & & & & & & 81 & & 9.73 & 0.00 & 1.42 & 0.23 & .35 & .39 & 0.16 \\
\hline & & & 0.55 & & 0.53 & 0.91 & .14 & 13.87 & 0.00 & .13 & 0.20 & 1.03 & 4.79 & 1.85 \\
\hline 329 & & 80 & 0.42 & 0.88 & 0.69 & 0.90 & .16 & 3.18 & 0.10 & .05 & 0.24 & 0.71 & 2.87 & 0.02 \\
\hline 331 & & 69 & 0.53 & 0.97 & 0.72 & 0.99 & .19 & 0.48 & 0.08 & .00 & 0.25 & .69 & 3.21 & 12.49 \\
\hline 332 & & & 1.03 & 0.62 & 043 & 0.59 & .21 & 2033 & 0.00 & 1.15 & 0.24 & 113 & 6.51 & 9.74 \\
\hline Aver. & & 0.08 & 0.72 & 0.74 & 0.55 & 0.82 & 1.17 & 15.49 & 0.03 & 1 & 0.23 & 1.0 & 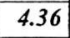 & 200 \\
\hline 324 & 38 & .63 & 0.26 & 0.73 & 0.60 & 0.87 & 1.41 & 2.88 & 0.23 & 0.79 & 0.34 & V.J1 & 1.10 & 3.01 \\
\hline 325 & 36 & .78 & 0.26 & 0.65 & 0.48 & 0.70 & 0.99 & 4.90 & 0.24 & 0.91 & 0.41 & 0.72 & 2.12 & 818 \\
\hline 326 & & .09 & 0.41 & 0.84 & 0.71 & .80 & 1.33 & 2.55 & 0.23 & 0.74 & 0.32 & 20 & 2.11 & 18 \\
\hline 327 & & .53 & 0.39 & & 0.69 & & 1.25 & 2.99 & 0.24 & 0.77 & 0.35 & 828 & 2.24 & 10.27 \\
\hline 328 & & .78 & 0.51 & & 0.82 & .88 & 1.55 & 1.79 & 0.19 & 0.70 & 0.32 & 0.21 & 2.17 & 10.89 \\
\hline 330 & & .73 & 0.55 & 0.95 & 0.93 & 1.09 & 1.63 & 2.33 & 0.15 & 0.69 & 0.24 & 0.22 & 2.20 & 1307 \\
\hline Aver. & & .76 & 0.40 & & 0.71 & & 1.50 & 2.51 & 0.21 & & 0.05 & & 2.10 & 0.0 \\
\hline 298 & & & 01 & & 98 & & 3 & .11 & 0.07 & U & 0.12 & 2 & 6.74 & 20.01 \\
\hline 299 & 83 & .85 & 0.02 & 1.09 & 1.14 & 1.39 & 1.67 & 1.71 & 0.02 & 0.46 & 0.05 & .12 & 4.44 & 21.26 \\
\hline 301 & 68 & 1.67 & 0.00 & 0.96 & 1.07 & 1.74 & 1.98 & 0.68 & 0.04 & 0.35 & 0.05 & .08 & 4.30 & 21.76 \\
\hline 303 & 06 & .21 & 0.01 & 1.22 & 1.28 & 27 & 1.78 & 1.39 & 0.05 & 0.45 & 0.08 & .12 & 4.41 & 20.56 \\
\hline 305 & & 21 & 0.22 & 99 & 1.07 & 57 & 1.72 & 0.44 & 0.04 & 0.41 & 0.09 & .11 & 4.54 & 21.10 \\
\hline 306 & 27 & 22 & 0.05 & ,04 & 1.00 & 37 & 1.52 & 0.80 & 0.03 & 0.46 & 0.08 & 13 & 4.82 & 21.14 \\
\hline 307 & 55 & .47 & 11 & .04 & 1.01 & 51 & 1.59 & 0.70 & 0.07 & 0.47 & 0.10 & .10 & 5.26 & 20.89 \\
\hline 308 & & .56 & .09 & 1.00 & 1.02 & 1.65 & 1.54 & 0.49 & 0.06 & 0.41 & 0.08 & .12 & 4.60 & $21.4 \mathrm{~J}$ \\
\hline & & & & 81 & & & 1.17 & & & & & & & 21.93 \\
\hline & & & & & & & & & & & & & 3.12 & 22.18 \\
\hline 311 & & 1.02 & 0.42 & 0.88 & 1.03 & 1.41 & 1.04 & 1.17 & 0.05 & 0.47 & 0.09 & 15 & 5.39 & 20.48 \\
\hline 312 & & 1.12 & 0.31 & 0.84 & 1.16 & 1.65 & 1,93 & $0.4 \mathrm{~J}$ & 0.04 & 0.39 & 0.07 & 0.06 & 4.53 & 21.33 \\
\hline 316 & 00 & 43.43 & 0.10 & 1.04 & 1.00 & 1.20 & 1.57 & 1.69 & 0.06 & 0.57 & 0.14 & 0.17 & 5.78 & 20.55 \\
\hline 320 & & 1.61 & 0.42 & 1.00 & 1.12 & 1.37 & 1.65 & & 0.03 & 0.53 & 0.08 & 0.16 & 5.89 & 21.05 \\
\hline 321 & 0.66 & 42.26 & 0.26 & 0.89 & 1.06 & 1.50 & 1,69 & 0.46 & 0.02 & 0.39 & 0.07 & 0.08 & 4.88 & 21.88 \\
\hline 322 & & 43.16 & 0.13 & 0.80 & 1.40 & 1.74 & 2.04 & 0.21 & 0.02 & 0.29 & 0.03 & 0.07 & 2.52 & 21,92 \\
\hline 323 & 1.06 & 41.77 & 0.36 & 1.21 & 1.38 & 1.26 & 1.69 & 1.14 & 0.01 & 0.53 & 0.07 & 0.19 & 5.35 & 20.78 \\
\hline . & 1.13 & 2.17 & 0.17 & 0.98 & 1.11 & 1.47 & 1.14 & 0.70 & 0.04 & 0.44 & 0.08 & 0.12 & 4.17 & 1.19 \\
\hline
\end{tabular}


ty. This variability in element contents has also been shown by some SEM maps (Fig.12), which allow the visualization of the clear zonation in the distribution of $\mathrm{Si}, \mathrm{Al}, \mathrm{Ce}, \mathrm{Mn}, \mathrm{Fe}$ e Ba. The clearer areas correspond to zones in which the elements are in higher concentration, while the darker areas correspond to lower concentrations, which are also represented by a lower resolution (higher graininess) of the map.

In the first row, beside the image of the examined fragment, the maps for $\mathrm{Ca}$ and Co are reported, which show a rather homogeneous distribution and a generally low concentration. It is also evident that the two groups, $\mathrm{Si}, \mathrm{Al}, \mathrm{Ce}$ (second row)

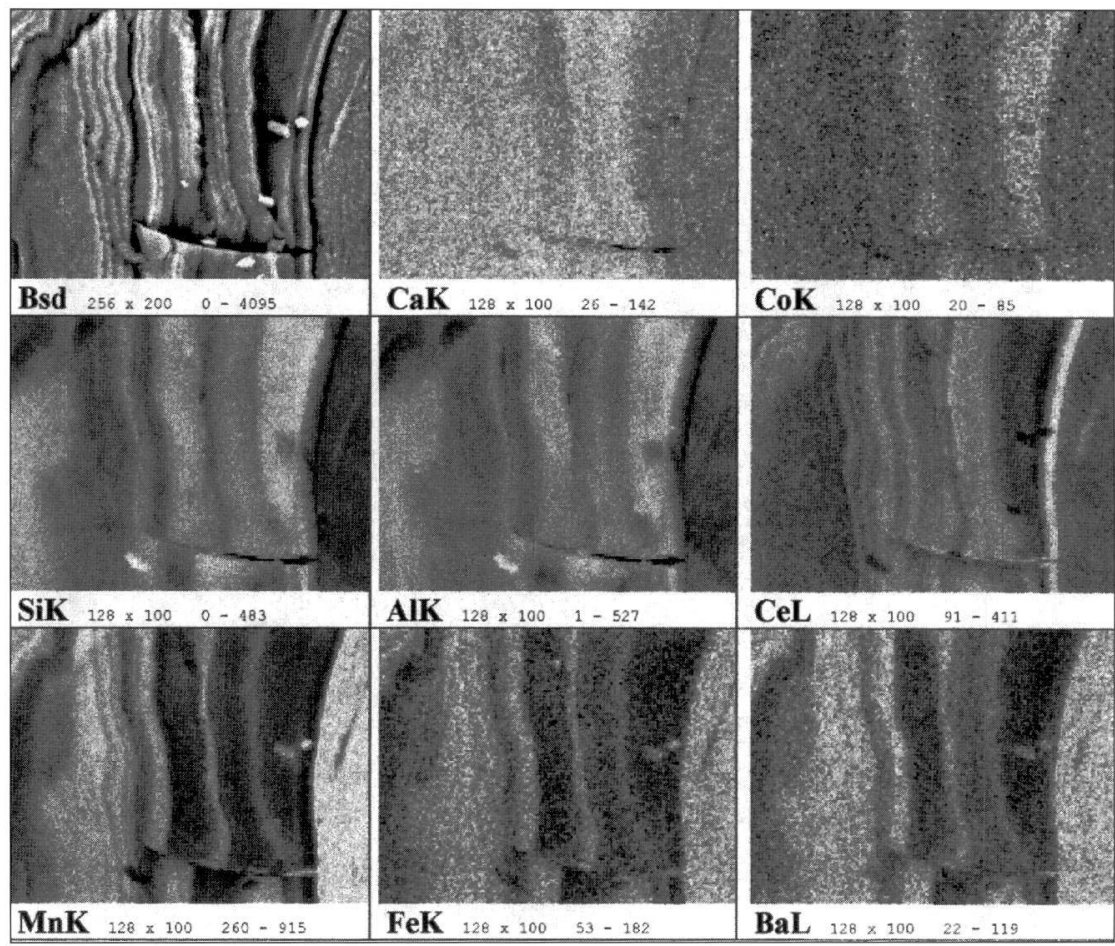

Fig. 12- SEM image of the fragment of Fig. $11 \mathrm{D}$ and distribution maps for Ca and Co (first row second and third images), for $\mathrm{Si}, \mathrm{Al}$ and $\mathrm{Ce}$ (second row) and for $\mathrm{Mn}, \mathrm{Fe}, \mathrm{Ba}$ (Third row). Explanation in text.

and $\mathrm{Mn}, \mathrm{Fe}, \mathrm{Ba}$ (third row), are not only present zonations but are also complementary to each other: the areas with higher $\mathrm{Si}, \mathrm{Al}, \mathrm{Ce}$ content have always a lower $\mathrm{Mn}, \mathrm{Fe}, \mathrm{Ba}$ content and the reverse. In the figure the maps for $\mathrm{O}, \mathrm{Mg}, \mathrm{P}, \mathrm{S}$ and $\mathrm{K}$ are not reported because they have an homogeneous distribution similar to that of $\mathrm{Ca}$. 
In order to make evident the relative relationships between the most variable elements, some color maps have been prepared in which the red and green represent, respectively, the couple Al-Si, Fe-Ba, Mn-Si (Fig. 13) and Al-Ba, Mn-Ce, Ba-Ce (Fig. 14). If the overlapping of the red and green of the different couples gives rise to yellow, it means that there is a similar distribution for the two elements, while if the result is red or green it indicates a clear prevalence of related elements.

The lack of single crystals avoided the possibility to verify if this strongly zonated distribution was due to the presence in the same sample of several different mineralogical phases or (less probably) to a single phase with a highly variable chemical composition.

Therefore, even if the powder spectrum closely agrees with that of lithiophorite in the literature, it cannot be excluded that the Perolas lithiophorite deposited intimately mixed with other amorphous or low crystalline Mn oxides, as referred by Ostwald (1988) for other Mn minerals. The same Author suggests that the pres-

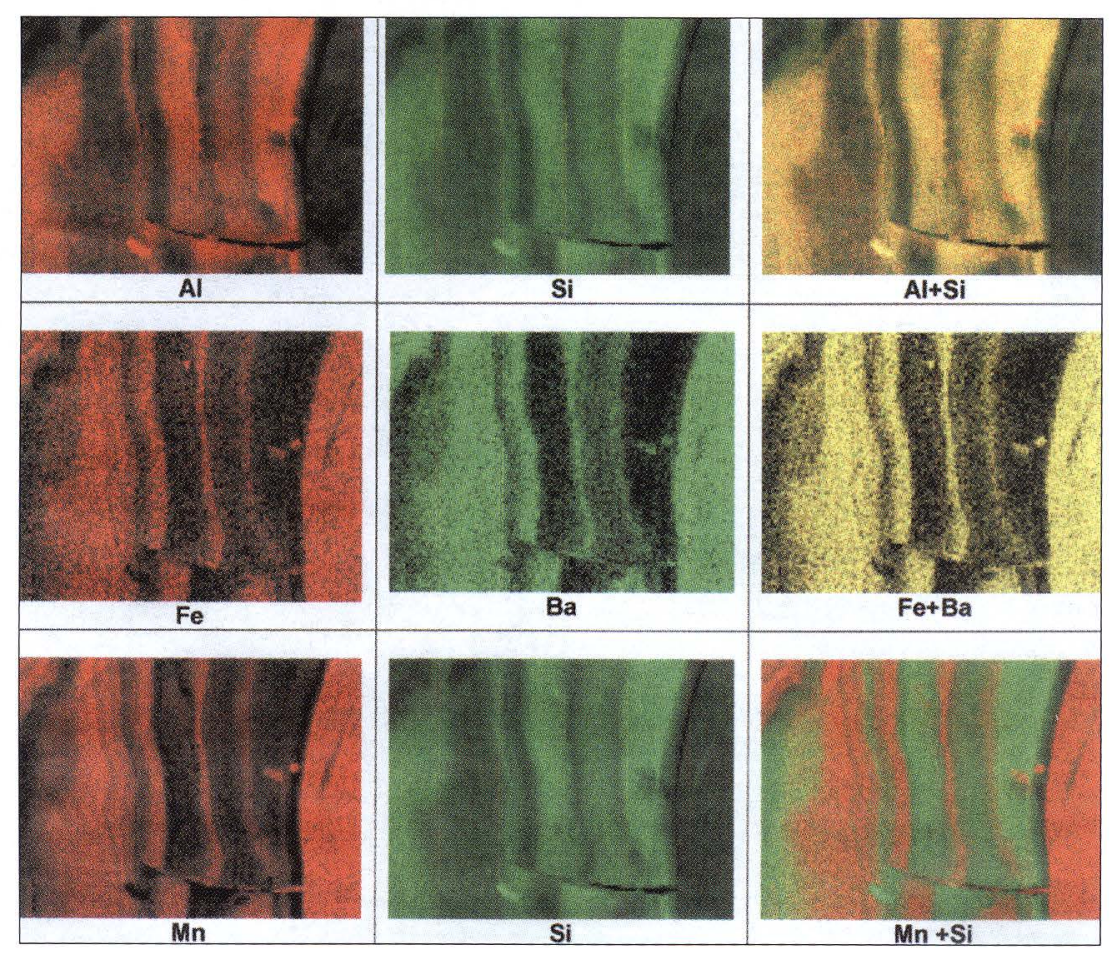

Fig. 13-SEM colour maps and overlap maps for Al-Si, Fe-Ba, Mn-Si. Explanation in text. 


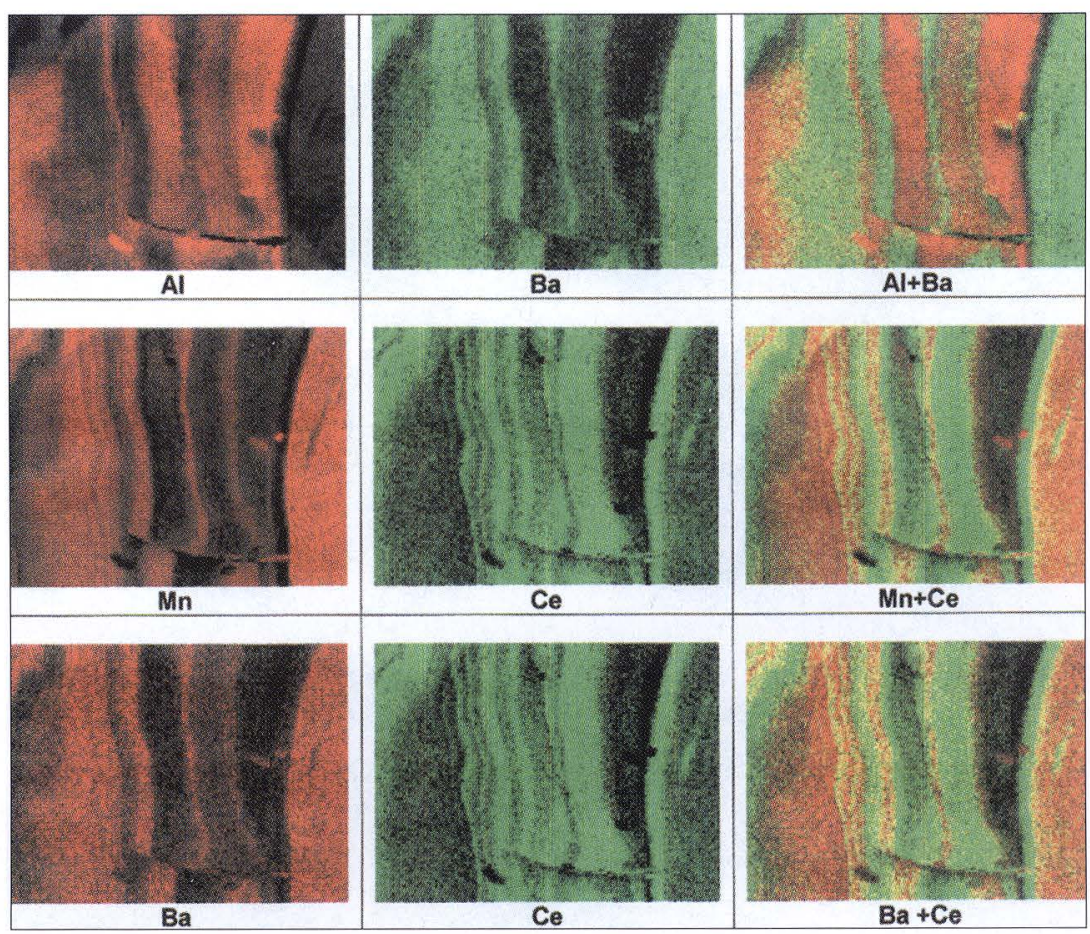

Fig. 14- SEM colour maps and overlap maps for Al-Ba, Mn-Ce and Ba-Ce. Explanation in text.

ence of transition metals like $\mathrm{Co}^{2+}(0.72 \AA), \mathrm{Ni}^{2+}(0.69 \AA), \mathrm{Cu}^{2+}(0.76 \AA), \mathrm{Zn}^{2+}$ $(0.74 \AA)$ in the lithiophorite is not the simple result of a diadochic replacement of $\mathrm{Mn}^{2+}(0.80 \AA), \mathrm{Mn}^{4+}(0.60 \AA)$ and $\mathrm{Li}^{+}(0.68 \AA)$ ions in the structure, but it may derive from a hybrid of "pure" lithiophorite and absolane (Ostwald, 1984).

On the other hand, if the hypothesis of a single phase was the true one, it should be extremely difficult to justify the presence of large radius like $\mathrm{Ce}^{2+}(1.07 \AA) \mathrm{e}$ $\mathrm{Ba}^{2+}(1.54 \AA)$ in the, even very open, structure of lithiophorite. The peculiar chemical variance of the Perolas lithiophorite may be better explained by taking into account the genetic mechanisms of the Mn oxides and the easy way in which topotactic transformations happens between "tunnel structures" and "layer structures of phyllomanganates".

Burns \& Burns (1978) suggested a genetic mechanism in which the initial step is represented by the aqueous crystallization products of $\mathrm{Mn}^{2+}$ as groups of $\left[\mathrm{Mn}^{4+}\right.$ $\mathrm{O}_{6}$ ] octahedra, which in turn act as templates for tunnel development only if appro- 
priate ions such as $\mathrm{Ba}^{2+}, \mathrm{K}^{+}, \mathrm{Na}^{+}, \mathrm{Ni}^{2+}, \mathrm{Cu}^{2+}, \mathrm{Zn}^{2+}$ are present. The tunnel structures stabilized by water molecules may convert into smaller and more stable ones in the presence of these accessory large radius ions. The possibility of topotactic transformations must be also taken into consideration. By this mechanism an initial crystal structure converts into a new one by means of a solid state reaction. These transformations may be partial or complete. For instance, Ostwald (1988) proposed that the layering of the pisoliths of Groote Eylandt involves periodic transformations from larger tunnels, containing $\mathrm{Ba}$ (romanechite), into dense chain structures without barium (pyrolusite). Many other examples are reported by the same Author for weathering zones, mainly in tropical areas, resulting from the action of surface or subsurface water.

In the case of Perolas Cave, the flow regimen of the underground river, which is characterized by sudden floods (carrying lot of organics into the karst from the Atlantic forest) and long periods of base level (in which the interstitial waters of the dried portions of the main gallery are in direct contact with the oxygen of the cave atmosphere) seems to allow the best environmental conditions for the deposition of this mineral, all the elements of which are surely fairly common in the rock and/or in the sediment of the catchment area of the Perolas-Santana karst system.

\section{Final remarks}

The present study, even if it only concerns a part of the Perolas-Santana karst system, has detected at least two new cave minerals for this system, one of them (the lithiophorite) being extremely rare and only known from a few caves in the world. The presence of secondary illite must be confirmed by other studies even if it seems reasonable that this mineral has develop secondarily in Perolas Cave due to the favourable environmental conditions therein.

Thanks to these new findings, the Perolas-Santana karst system (even if not exhaustively studied) is the most important natural cavity of Brazil from the mineralogical point of view, hosting at least 10 different cave minerals (see Tab. 1). Moreover, the study performed on the lithiophorite evidenced the complex chemical behaviour of this mineral and demonstrated that only the chemical analyses of crystals over a certain size, and not of aggregates of micron-sized crystallites, may give reliable information on its chemical composition. 


\section{Acknowledges}

The authors wish to thank all the PETAR (Parque Estadual e Turistico do Alto Ribeira) team for the help given in the field, the Istituto Florestal for the permission to make the research inside the Perolas-Santana system, the guide Valdecir dos Santos for the support given inside the caves. The authors thank also dr. P.L. Fabbri and M. Tonelli of C.I.G.S. of the University of Modena and Reggio Emilia for the precious help given at the electronic microscope, Mrs T. Giliberti for the atomic adsorption analyses, dr. S. Bigi e D. Malferrari respectively for microprobe and thermogravimetric analyses.

\section{References}

AYUB S., CUCCHI F., FORTI P., ZINI L. 2001. The evaluation of the pollution intrinsic vulnerability of karst aquifers in a tropical environment using the point count system SINTACS. Proc. XIII Int. Spel. Congr., Brasilia, S-1,147.

BARBIERI A. J. 1993. Depósitos minerais secundários das cavernas Santana, Pérolas e Lage branca, Município de Iporanga - São Paulo. Dissertação de mestrado, Inst. Geociências, Univ. São Paulo, 96 pp.

BURNS V. M., BURNS R.G. 1978. Post-depositional metal enrichment process es inside manganese nodules from the north equatorial Pacific. Earth Planet. Sci. Lett., 39, 341-348.

CAMPANHA G. A. C. 1991. Tectônica proterozóica na alto e médio vale do Ribeira, Esdado de São Paulo e Paraná. PhD Thesis, Geoscience Institute, University of São Paulo, 296 pp.

DONOVAN J. J. 1995. PROBE: PC - based data acquisition and processing for electron microprobes. Advanced Microbeam 1995, 4217C Kings Graves Road, Vienna, $\mathrm{OH}, 44473$.

FORTI P., CUCCHI F., AYUB S. 2001. Le "marmitte di corrosione" della Grotta Perolas (San Paolo, Brasile). Le Grotte d'Italia s.V, 2, (p. 15 - 24).

FRENZEL A. 1870. Lithiophorit, ein lithiohältiges Manganerz. J. praktische Chemie, 110, 203-206.

GUTJAHR M.R. 1993. Critérios relacionados à compartimentação climática de bacias 
hidrográficas: a bacia do Rio Ribeira de Iguape. Thesis, Dept. of Geography, University of São Paulo, 90 pp.

HILL C., FORTI P. 1997. Cave minerals of the World. Nat. Spel. Soc., 464 pp.

KARMANN I. 1994. Evolução e Dinâmica atual do Sistema Cárstico do Alto Vale do Rio Ribeira de Iguape, Sudeste do Estado de São Paulo. São Paulo, PhD Thesis, Geoscience Institute, University of São Paulo, 228 pp.

KARMANN I., SANCHEZ L. E. 1986. Speleological Provinces in Brazil. IX Int. Spel. Congr., Barcelona, 1, p.151-153.

LABEGAlini J. A., AUleR A. 1997. Caverna Santana. In Hill C. A. \& Forti P. "Cave Minerals of the World", 340-342.

LAZAREV J. S., PHILENCO G. D. 1976. Geological and mineralogical peculiarities of Guardakskoy karst cave. Peshchery, 16, 45-63 (in russian).

MALTSEV V. A. 1993. Minerals of the Cupp - Coutun karst cave system, southeast Turkmenistan. World of Stones, Moskow, 2, 5-30.

MITCHELL R.S., MEINTZER R.E. 1967. Lithiophorite from Charlottesville, Virginia. Amer. Mineral., 52, 1545-1549.

OTSWALD J. 1984. Two varieties of lithiophorite in some Australian deposits. Mineral. Mag., 48, 383-388.

OTSWALD J. 1988. Mineralogy of the Groote Eylandt manganese oxides: A review. Ore Geology Reviews, 4, 3-45.

POST J.E., APPLEMAN D.E. 1994. Crystal structure refinement of lithiophorite. Amer. Mineral., 79, 370-374.

RAMSDELL L.S. 1932. An X-ray study of psilomelane and wad. Amer. Mineral., 17, 143149.

SHOPOV Y. Y. 1993. Genetic classification of cave minerals. Proc. $10^{\text {th }}$ Int. Congr. Speleol., Beijing (pubbl. 1993-94), 101-105.

URBANI F. 1996. Venezuelan Cave Minerals. A Review. Bol. Soc. Venezolana de Espeleologia, No. 30 ,

URBANI F., ZAWIDSKI P., KOISAR B. 1976. Observaciones geológicas de la meseta de 
Sarisariñama, Estado Bolívar. Bol. Inf. Assoc. Venez. Geol. Mineral. Petrol., 19 (2), 77-86.

WADSLEY A.D. 1952. The structure of lithiophorite, $(\mathrm{Al}, \mathrm{Li}) \mathrm{MnO}_{2}(\mathrm{OH})_{2}$. Acta Cryst., 5, 676-680. 